\title{
PENERAPAN MODEL PEMBELAJARAN COOPERATIVE INTEGRATED READING AND COMPOSITION UNTUK MENINGKATKAN HASIL BELAJAR SISWA KELAS V SDN 4 BEBETIN KABUPATEN BULELENG
}

\author{
I Komang Muliantara \\ Universitas Pendidikan Ganesha \\ komangmuliantara18@gmail.com
}

\begin{abstract}
This study aims to improve learning outcomes class V students. This research is classroom action research. Based on the results of initial observations, student learning outcomes are still low. This study uses the Cooperative Integrated Reading and Composition learning model. This research was conducted at SDN 4 Bebetin in fifth grade students with a total of 15 students, consisting of 3 male students and 12 female students. Based on the results of the study, there was an increase in student learning outcomes from cycle I to cycle II. This is evidenced in the first cycle obtained 6 students (40\%) who have completed and 9 students $(60 \%)$ have not completed with an average value of 67 . Cycle II increased to 12 students (87\%) completed and 3 students (13\%) incomplete with an average score of 89 . From the results of cycle I and cycle II, it can be concluded that the application of the CIRC learning model can improve learning outcomes fifth grade students at SDN 4 Bebetin, Buleleng Regency.
\end{abstract}

Keywords: Cooperative Integrated Reading and Composition (CIRC), Learning Outcomes.

\begin{abstract}
ABSTRAK
Penelitian ini bertujuan untuk meningkatkan hasil belajar siswa kelas V. Penelitian ini adalah penelitian tindakan kelas. Berdasarkan hasil observasi awal, hasil belajar siswa masih rendah. Penelitian ini menggunakan model pembelajaran Cooperative Integrated Reading and Composition. Penelitian ini dilaksanakan di SDN 4 Bebetin pada siswa kelas V dengan jumlah 15 siswa, yang terdiri dari 3 siswa laki- laki dan 12 siswa perempuan. Berdasarkan hasil penelitian, terjadi peningkatan hasil belajar siswa dari siklus I sampai dengan siklus II. Hal ini dibuktikan pada siklus I diperoleh 6 siswa (40\%) yang tuntas dan 9 siswa (60\%) belum tuntas dengan nilai rata- rata 67. Siklus II meningkat menjadi 12 siswa (87\%) tuntas dan belum tuntas 3 siswa (13\%) dengan nilai rata- rata 89. Dari hasil siklus I dan siklus II dapat disimpulkan bahwa penerapan model pembelajaran CIRC dapat meningkatkan hasil belajar siswa kelas V SDN 4 Bebetin Kabupaten Buleleng.
\end{abstract}

Kata kunci: Model Cooperative Integrated Reading and Composition (CIRC), Hasil Belajar.

\section{PENDAHULUAN}

Pendidikan merupakan suatu usaha yang disadari untuk mengembangkan kepribadian dan keterampilan manusia yang dilaksanakan di dalam maupun di luar sekolah dan berlangsung seumur hidup (Salam, 2002:101). Pendidikan sangatlah penting, tanpa pendidikan manusia akan sulit berkembang bahkan akan semakin terbelakang. Peranan pendidikan harus diarahkan untuk menghasilkan manusia yang berkualitas dan mampu bersaing. Pendidikan memegang peranan sangat penting dan strategis dalam membangun masyarakat. Pendidikan merupakan suatu kegiatan yang tidak terpisahkan dari kehidupan manusia bahkan sejak awal manusia ada.

Undang-undang Republik Indonesia No 20 tahun 2003 tentang Sistem Pendidikan Nasional menyebutkan bahwa Pendidikan adalah usaha sadar dan terencana untuk mewujudkan suasana belajar dan proses pembelajaran agar peserta didik secara aktif dapat mengembangkan potensi dirinya untuk memiliki kekuatan spiritual, keagamaan, pengendalian 
diri, kepribadian, kecerdasan, akhlak mulia, serta ketrampilan yang diperlukan dirinya masyarakat dan negara. Hal ini merupakan suatu perwujudan dari salah satu tujuan nasional Indonesia yaitu mencerdaskan kehidupan bangsa.

Pendidikan di Indonesia mengalami perubahan kurikulum, yang sebelumnya KTSP sekarang menjadi kurikulum 2013 yang dinyatakan sudah selesai direvisi pada awal tahun 2016. Kurikulum 2013 yaitu kurikulum berbasis kompetensi yang merupakan konsep kurikulum yang menitikberatkan pada pengembangan karakter dan kemampuan melakukan (kompetensi) tugas-tugas dengan ketentuan standar tertentu, sehingga hasilnya dapat dirasakan oleh siswa, seperti penguasaan terhadap kompetensi materi tertentu. Tidak hanya berbasis pada kompetensi, hal terpenting dalam penerapan Kurikulum 2013 adalah penerapan pendidikan karakter. Pada kurikulum 2013 pembelajaran tematik terpadu diberlakukan di seluruh kelas di sekolah dasar, yang meliputi seluruh mata pelajaran yang disajikan secara terpadu dengan tema sebagai pemersatu. Kurikulum 2013 bertujuan memberikan ilmu pengetahuan secara utuh kepada siswa dan tidak terpecah-pecah. Kurikulum ini menekankan pada keaktifan siswa untuk menemukan konsep pelajaran dengan guru berperan sebagai fasilitator (Efendi dalam Darsana, 2019:2).

Sebagaimana kita ketahui bahwa dalam Kurikulum 2013, penekanan pada Sekolah Dasar diarahkan dalam aspek keterampilan siswa. Secara teori, apa yang diinginkan dalam kurikulum 2013 memang sangat bagus. Akan tetapi, dalam pelaksanaan kurikulum ini, masih sangat banyak pendukung- pendukung pembelajaran yang belum memadai dan dipersiapkan dengan matang.

Bahasa Indonesia dan PPKn pada pada pembelajaran Tematik merupakan mata pelajaran dasar pada jenjang pendidikan formal yang sangat penting, khususnya pada pelajaran Bahasa Indonesia. Setiap peserta didik diharuskan mampu menguasai Bahasa Indonesia dengan baik. Selain mata pelajaran yang diikutkan dalam ujian nasional, Bahasa Indonesia merupakan bahasa Nasional yang sering digunakan dalam bahasa sehari- hari.

Salah satu keterampilan dasar yang harus dikuasai oleh siswa adalah keterampilan membaca. Karena dengan membaca siswa mampu memahami kalimat efektif pada teks eksplanasi dalam suatu bacaan. Pembelajaran Bahasa Indonesia Sekolah Dasar (SD) kajian teoritis kearah implementasi pembelajaran Bahasa Indonesia sebagai alat pemahaman guru SD dalam melaksanakan pembelajaran Bahasa Indonesia secara benar.

Pengembangan melalui pendidikan formal dimulai dari SD. Jenjang sekolah ini berfungsi sebagai pusat budaya dan pembudayaan baca tulis (Zulela, 2012:1). Proses belajar telah dimulai sejak kecil, pada umur 1,6 s.d 7 tahun. Masa ini adalah masa estetik / masa keindahan, anak memandang dan mengamati dunia sekelilingnya dengan suatu keindahan. Ia asyik tenggelam dan bermain, mendengar cerita yang sesuai dengan fantasinya, dan mencoba mengenal benda- benda yang ada disekitarnya dan tertarik terhadap benda- benda yang warna mencolok, aneh menurutnya, dan berusaha untuk mengenalinya (Yamin, 2012: 122).

Dalam pembelajaran Bahasa Indonesia guru merupakan pihak yang berhubungan langsung dengan siswa, sehingga dalam memberikan evaluasi diharapkan lebih akurat, objektif, dan mengoptimalkan pembelajaran. Dalam hal itu guru akan menemukan berbagai masalah, misalnya masalah kecakapan mengajar yang meliputi ketepatan pemilihan model, metode, pendekatan, strategi pembelajaran, motivasi, sampai penggunaan media yang menarik, sehingga dapat mempengaruhi hasil belajar siswa. 
Belajar merupakan proses orang memperoleh kecakapan ketrampilan, dan sikap. Belajar dimulai dari masa kecil sampai akhir hayat seseorang. Anak- anak membutuhkan pengetahuan awal, dan memiliki keyakinan, kepercayaan yang semu, disamping itu anak-anak memiliki banyak pengharapan akan sesuatu, pada saat itu anak- anak membutuhkan banyak belajar dan memungkinkan memberi pengetahuan kepadanya (Yamin, 2012:120). Belajar dapat didefinisikan sebagai suatu proses dimana suatu organisme berubah perilakunya sebagai akibat pengalaman, belajar dan mengajar merupakan dua konsep yang tidak dapat dipisahkansatu sama lain. Dua konsep ini menjadi terpadu dalam satu kegiatan dimana terjadi interaksi antara guru dan siswa, serta siswa dengan siswa pada saat pemebelajaran berlangsung (Susanto, 2013:14).

Kegiatan belajar akan memperoleh hasil dari apa yang dipelajari atau diajarkan, hasil itu disebut hasil belajar. (Dimyati, 2006:110) "hasil belajar adalah hasil nyata yang diperoleh siswa dalam kegiatan belajar dalam periode tertentu atau perubahan yang terlihat atau tampak pada seseorang melalui pengalaman dan latihan". Perubahan tersebut misalnya penambahan pengetahuan, kebiasaan, perubahan sikap, dan pandangan terhadap suatu hal, serta adanya keterampilan- keterampilan. Sedangkan Karti Soeharto (dalam Agung 2005:74) mengatakan bahwa belajar ditandai oleh ciri- ciri yaitu: (1) disengaja dan bertujuan, (2) tahan lama, (3) bukan karena kebetulan, (4) bukan karena kematangan dan pertumbuhan.

Hasil belajar setiap siswa berbeda-beda antara satu dengan yang lainnya. Hal ini disebabkan karena setiap siswa memiliki latar belakang dan karakteristik individual yang berbeda. Hasil belajar seseorang yang didapatkan dipengaruhi oleh beberapa faktor, yaitu faktor dalam dan faktor luar atau lingkungan. (Sudjana, 2005:39) faktor dalam yaitu faktor yang datang dari dalam diri siswa terutama kemampuan yang dimiliki. Di samping itu ada juga faktor lain seperti, motivasi, minat dan perhatian, sikap dan kebiasaan belajar, ketekunan, sosial ekonomi, faktor fisik dan psikis. Faktor luar atau lingkungan dapat berupa kualitas pengajaran, yang dimaksud adalah efektif tidaknya kegiatan pembelajaran yang dilakukan guru. Selain itu faktor luar yang mempengaruhi dapat berupa: (1) besarnya kelas atau banyak sedikitnya siswa yang belajar, (2) suasana belajar, suasana belajar yang kondusif akan memberi peluang mencapai hasil belajar yang optimal, (3) fasilitas dan sumber belajar yang tersedia, fasilitas dan sumber belajar harus tersedia dengan baik, selain itu penggunaan alat peraga sebagai sumber belajar akan berpengaruh baik pada hasil belajar siswa. Sedangkan Carrol (dalam Sudjana, 2005:40) hasil belajar yang dicapai siswa dipengaruhi oleh lima faktor yaitu: (1) bakat pelajar, (2) waktu yang tersedia untuk belajar, (3) waktu yang diperlukan siswa untuk menjelaskan pelajaran, (4) kualitas pengajaran, dan (5) kemampuan individu.

Dari dua pendapat tersebut, faktor-faktor yang mempengaruhi hasil belajar terdiri dari dua, yaitu faktor dari dalam diri siswa yang berupa bakat, motivasi, minat dan perhatian, sikap dan kebiasaan belajar, ketekunan, sosial ekonomi, faktor fisik dan psikis. Faktor luar atau dari lingkungan dapat berupa kualitas pengajaran.

Sesuai hasil refleksi awal hasil belajar siswa kelas V SDN 4 Bebetin Kabupaten Buleleng ditemukan beberapa masalah dalam pembelajaran Bahasa Indonesia. Salah satunya adalah kurangnya kemampuan siswa dalam memahami kalimat efektif pada teks eksplanasi yang telah dibaca. Hal ini dibuktikan dengan hasil tes evaluasi awal siswa kelas V SDN 4 Bebetin Kabupaten Buleleng yang diperoleh, masih banyak siswa yang mendapatkan nilai di bawah Kriteria Ketuntasan Minimal (KKM). KKM yang telah ditetapkan sekolah yaitu 75. Secara klasikal nilai siswa belum memenuhi KKM. Dari 15 siswa, hanya 4 siswa (27\%) yang dapat memenuhi nilai KKM, sedangkan sisanya sebanyak 11 siswa (73\%) nilainya masih berada di bawah KKM. Nilai rata-rata pra siklus sebesar 65,00. 
Salah satu cara untuk mengatasi permasalahan yang terjadi pada siswa kelas V SDN 4 Bebetin Kabupaten Buleleng adalah dengan menerapkan model pembelajaran Cooperative Integrated Reading and Composition. Model pembelajaran hampir sama dengan strategi. Model dapat dipahami sebagai suatu kerangka konseptual yang digunakan sebagai pedoman untuk melakukan suatu kegiatan. Model dirancang untuk mewakili realitas yang sesungguhnya walaupun model itu sendiri bukanlah realitas dari dunia yang sebenarnya. Oleh karenanya, model pembelajaran adalah kerangka konseptual yangdigunakan sebagai pedoman dalam melakukan kegiatan pembelajaran.

Model pembelajaran Cooperative Integrated Reading and Composition (CIRC) dalam pembelajaran setiap siswa bertanggung jawab terhadap tugas kelompok. Setiap anggota kelompok mengeluarkan ide-ide untuk memahami suatu konsep dan menyelesaikan tugas sehinngga membentuk pemahaman dan pengalaman belajar yang lama (Huda, 2014: 221). Model pembelajaran Cooperative Integrated Reading and Composition dikembangkan untuk menyokong pendekatan pembelajaran tradisional pada mata pelajaran bahasa yang disebut kelompok membaca berbasis ketrampilan. Setiap kelompok diminta untuk saling membantu untuk menunjukkan aktivitas pengembangan ketrampilan berbahasa (Faturrohman, 2015:79).

Langkah-langkah pembelajaran dari model pembelajaran Cooperative Integrated Reading and Composition menurut Steven, dkk (dalam Huda, 2014:222), yaitu: (1) guru membentuk yang masing-masing terdiri dari 4 siswa, (2) guru memberikan wacana sesuai dengan topik pembelajaran, (3) siswa bekerja sama saling membacakan dan menemukan ide pokok kemudian memberikan tanggapan terhadap wacana yang ditulis pada lembar kertas, (4) siswa mempresentasikan/membacakan hasil diskusi kelompok, (5) guru memberikan penguatan, dan (6) guru dan siswa bersama-sama memberikan kesimpulan.

Dari setiap fase diatas menurut Huda, (2014:222-223) dapat dilihat beberapa tahap: (1) pengenalan konsep Pada fase ini guru mulai mengenalkan suatu konsep atau istilah baru yang mengacu pada hasil penemuan selama eksplorasi, (2) eksplorasi dan aplikasi memberikan peluang kepada siswa untuk mengungkapkan pengetahuan awal, mengembangkan pengetahuan baru dan menjelaskan fenomena alami yang mereka alami dengan bimbingan guru, dan (3) publikasi pada fase ini, siswa mampu mengkomunikasikan hasil temuan-temuan serta membuktikan dan memperagakan materi yang telah dibahas.

Kelebihan model pembelajaran Cooperative Integrated Reading and Composition (CIRC) menurut Saifulloh (dalam Huda, 2014:221) adalah: (a) Pengalaman dan kegiatan belajar siswa akan selalu relevan dengan tingkat perkembangan anak, (b) kegiatan yang dipilih sesuai dengan minat dan kebutuhan siswa, (c) seluruh kegiatan pembelajaran lebih bermakna sehingga hasil belajar siswa akan bertahan lebih lama, (d) dapat menumbuhkan ketrampilan berfikir siswa, (e) bermanfaat sesuai dengan permasalahan yang sering timbul dalam lingkungan siswa, (f) dapat menumbuh kembangkan interaksi sosial siswa, (g) menumbuhkan motivasi belajar siswa, dan (h) memperluas wawasan siswa dan aspirasi guru dalam mengajar.

Kelemahan model pembelajaran Integrated Reading and Composition (CIRC) adalah: (a) model ini kurang tepat jika diterapkan pada peserta didik yang kurang mampu dalam membaca, (b) jika diterapkan terlalu sering siswa akan merasa bosan, dan (c) peserta didik merasa jenuh jika harus membaca terlalu lama.

Berdasarkan pemaparan tersebut, maka dipandang perlu diadakan penelitian tentang penerapan model pembelajaran Cooperative Integrated Reading and Composition terhadap hasil belajar siswa kelas V SDN 4 Bebetin Kabupaten Buleleng. Tujuan dari penelitian ini 
adalah untuk mengetahui apakah model pembelajaran Cooperative Integrated Reading and Composition dapat meningkatkan hasil belajar siswa kelas V SDN 4 Bebetin Kabupaten Buleleng.

\section{METODE}

Jenis penelitian yang digunakan oleh peneliti adalah Penelitian Tindakan Kelas (PTK) atau yang sering dikenal sebagai Classrom Action Research. Daryanto (2011: 14) mengemukakan penelitian tindakan kelas adalah penelitian yang dilakukan oleh guru didalam kelasnya sendiri melalui refleksi diri, dengan tujuan untuk memperbaiki kinerjanya sebagai guru, sehingga hasil belajar siswa menjadi meningkat. Menurut Sanjaya (2013:149) penelitian tindakan adalah proses pengkajian masalah pembelajaran di dalam kelas melalui refleksi diri dan upaya untuk memecahkannya dengan cara melakukan berbagai tindakan yang terencana dalam situasi nyata serta menganalisis setiap pengaruh dari tindakan tersebut. Penelitian tindakan kelas adalah suatu pencermatan terhadap kegiatan belajar berupa sebuah tindakan yang sengaja dimunculkan dan terjadi dalam sebuah kelas secara bersamaan (Arikunto, 2006:130). Penelitian Tindakan Kelas (PTK) adalah penelitian yang dilakukan oleh guru dengan tujuan untuk memperbaiki dan meningkatkan proses pembelajaran. Penelitian ini dilakukan dengan mencermati kegiatan proses pembelajaran dan menemukan permasalahan yang terdapat baik dari perencanaan, proses, dan hasil pembelajaran. Dari permasalahan tersebut, kemudian diberikan suatu tindakan sebagai upaya untuk memperbaikinya.

Tempat pelaksanaan Penelitian Tindakan Kelas (PTK) ini dilaksanakan di SDN 4 Bebetin. SDN 4 Bebetin berlokasi di Desa Bebetin, Kecamatan Sawan Kabupaten Buleleng. Waktu pelaksanaan penelitian ini adalah dari bulan Januari sampai dengan bulan April tahun pelajaran 2020/2021.

Subjek penelitian ini diambil dari siswa kelas V SDN 4 Bebetin Kabupaten Buleleng. Jumlah siswa kelas V SDN 4 Bebetin Kabupaten Buleleng sebanyak 15 siswa, yang terdiri dari 3 siswa laki-laki dan 12 siswa perempuan. Penelitian ini dipilih siswa kelas V karena hasil belajar awal diketahui masih rendah.

Objek penelitian merupakan sesuatu hal yang akan diteliti untuk mendapatkan data dengan tujuan tertentu dan kemudian dapat dijadikan pedoman untuk menarik kesimpulan. Untuk itu objek dari penelitian ini adalah peningkatan hasil belajar siswa kelas V SDN V Bebetin Kabupaten Buleleng setelah diterapkannya model pembelajaran Cooperative Integrated Reading and Composition.

Pelaksanaan penelitian tindakan kelas ini menggunakan rancangan dari Depdiknas (2011:12). Rancangan penelitian ini dilakukan dalam beberapa putaran atau siklus. Jumlah putaran tidak ditentukan karena indikator keberhasilan diukur dari kepuasan peneliti terhadap pencapaian hasil yang berupa perubahan perilaku subjek yang diteliti. Umumnya, tiap-tiap siklus penelitian tindakan berisi kegiatan: perencanaan, tindakan, observasi, dan refleksi. Alur pelaksanaan PTK yang dilakukan peneliti sebanyak 2 siklus. Jumlah pertemuan tiap siklus adalah tiga kali pertemuan. Pertemuan pertama dan kedua untuk tatap muka, sedangkan pertemuan ketiga pemberian tes. Rancangan siklus I berisi kegiatan: perencanaan, tindakan, observasi, dan refleksi. Rancangan siklus II hampir sama dengan siklus I. Jika pada siklus II juga belum memenuhi kriteria yang telah ditetapkan, maka akan dilanjutkan pada siklus III dan seterusnya. Sedangkan apabila pada siklus I, keaktifan belajar sudah memenuhi kriteria yang telah ditetapkan, maka pelaksanaan tindakan siklus II akan dijadikan perbandingan dengan siklus I. 
Untuk memperoleh data yang sesuai, diperlukan teknik pengumpulan data yang tepat. Dengan menggunakan teknik yang tepat, maka proses penelitian lebih jelas dan mudah untuk dilakukan serta menjadi sistematis sesuai dengan langkah langkah yang diambil. Dalam proses pengumpulan data diperlukan instrumen pengumpulan data. Dalam pengumpulan data yang benar, data yang akurat dapat diperoleh sesuai dengan standar yang ditetapkan. Teknik dan instrumen yang digunakan oleh peneliti observasi, tes, catatan lapangan, dan dokumentasi.

Observasi adalah kegiatan yang dilakukan dengan tujuan untuk mendapatkan data yang kemudian diolah sesuai dengan kebutuhan penelitian. Kegiatan pengamatan dilakukan untuk mengamati aktivitas guru dan siswa selama kegiatan pembelajaran dengan menerapkan model Treffinger. Instrumen yang digunakan adalah lembar observasi aktivitas guru, lembar observasi aktivitas siswa, dan lembar hasil belajar siswa pada aspek sikap.

Tes dilakukan untuk memperoleh data tentang hasil belajar siswa pada aspek pengetahuan. Sudjana (2005:35) menjelaskan bahwa tes adalah kumpulan pertanyaan yang diberikan kepada siswa untuk mendapatkan jawaban dari siswa dalam bentuk lisan, tulisan, dan praktik. Tipe soal yang digunakan meliputi level C4 (menganalisis).

Catatan lapangan berisi gambaran konkret dilapangan berupa pokok pengamatan atau wawancara. Catatan lapangan digunakan untuk mendapatkan data yang tidak terlihat melalui lembar observasi (Arikunto dkk, 2006: 78). Catatan ini diperlukan karena peneliti mengandalkan pengamatan dan wawancara dalam pengumpulan data di lapangan dalam penelitian kualitatif. Sehingga, catatan tersebut mempermudah dalam pelaksanaan penelitian. Pengamat menggunakan lembar catatan lapangan sebagai instrumen pengumpulan data.

Dokumentasi adalah proses pengumpulan data dan menganalisis dokumen, baik secara tertulis, gambar, maupun elektronik. Dokumentasi dilaksanakan selama pembelajaran berlangsung. Instrumen yang digunakan adalah kamera untuk mendapatkan data berupa foto aktivitas guru dan siswa selama pelaksanaan pembelajaran.

Instrumen yang digunakan untuk menilai hasil belajar siswa kelas V SDN 4 Bebetin adalah tes. Perangkat tes yang digunakan untuk mengumpulkan data adalah tes essai. Tes essai sebanyak 10 butir soal tiap siklus.

Data yang diperoleh dalam penelitian ini adalah data kuantitatif, yaitu: data hasil belajar siswa. Data mengenai hasil belajar dianalisis dengan menghitung nilai individu siswa, rata-rata kelas, dan persentase ketuntasan belajar siswa. Persentase ketuntasan belajar siswa dikonversikan dalam Penilaian Acuan Patokan (PAP) skala lima. Analisis data dilakukan setelah data penelitian tindakan kelas pada masing-masing siklus diperoleh.

Penelitian mengenai penerapan model pembelajaran Cooperative Integrated Reading and Composition pada siswa kelas V SDN 4 Bebetin Kabupaten Buleleng dikatakan berhasil jika nilai rata-rata hasil belajar siswa sebesar $\geq 75$ dengan persentase ketuntasan belajar sebesar $75 \%$ yang berada pada kategori tinggi.

\section{HASIL DAN PEMBAHASAN}

\section{HASIL}


Hasil tes evaluasi pada siklus I mengalami peningkatan dibandingkan dengan nilai pra siklus. Pada siklus I terdapat 6 siswa yang tuntas dan 9 siswa yang belum tuntas. Dengan demikian baru $40 \%$ dari jumlah keseluruhan siswa yang mencapai KKM. Hal ini menunjukkan bahwa hasil belajar siswa pada siklus I belum memenuhi target yang peneliti tentukan sebesar $75 \%$. Hasil tes evaluasi pada siklus I dapat dilihat seperti pada tabel 1 berikut ini.

Tabel 1. Hasil Tes Evaluasi Siklus I

\begin{tabular}{cccl}
\hline No & Nama & Nilai & \multicolumn{1}{c}{ Ket } \\
\hline 1 & Siswa 1 & 60 & Tidak Tuntas \\
2 & Siswa 2 & 80 & Tuntas \\
3 & Siswa 3 & 70 & Tidak Tuntas \\
4 & Siswa 4 & 70 & Tidak Tuntas \\
5 & Siswa 5 & 60 & Tidak Tuntas \\
6 & Siswa 6 & 80 & Tuntas \\
7 & Siswa 7 & 60 & Tidak Tuntas \\
8 & Siswa 8 & 75 & Tuntas \\
9 & Siswa 9 & 65 & Tidak Tuntas \\
10 & Siswa 10 & 70 & Tidak Tuntas \\
11 & Siswa 11 & 75 & Tuntas \\
12 & Siswa 12 & 65 & Tidak Tuntas \\
13 & Siswa 13 & 75 & Tuntas \\
14 & Siswa 14 & 75 & Tuntas \\
15 & Siswa 15 & 70 & Tidak Tuntas \\
& Rata-rata & $\mathbf{7 0 , 0 0}$ & \\
& Ketuntasan & $\mathbf{6 0 \%}$ & \\
\hline
\end{tabular}

Hasil tes evaluasi pada siklus II mengalami peningkatan yang cukup signifikan dibandingkan dengan siklus I. Pada siklus II, telah mencapai $87 \%$ dari seluruh siswa yang mencapai KKM yang telah ditentukan sekolah. Terdapat 13 siswa yang tuntas dan 2 siswa yang belum tuntas. Hasil belajar siswa sudah memenuhi target penelitian, yaitu sebesar $87 \%$ dari seluruh jumlah siswa mencapai KKM. Hasil tes evaluasi pada siklus II dapat dilihat seperti pada tabel 2 berikut ini.

Tabel 2. Hasil Tes Evaluasi Siklus II

\begin{tabular}{cccl}
\hline No & Nama & Nilai & \multicolumn{1}{c}{ Ket } \\
\hline 1 & Siswa 1 & 95 & Tuntas \\
2 & Siswa 2 & 90 & Tuntas \\
3 & Siswa 3 & 95 & Tuntas \\
4 & Siswa 4 & 90 & Tuntas \\
5 & Siswa 5 & 90 & Tuntas \\
6 & Siswa 6 & 90 & Tuntas \\
7 & Siswa 7 & 70 & Tidak Tuntas \\
8 & Siswa 8 & 90 & Tuntas \\
9 & Siswa 9 & 70 & Tidak Tuntas \\
10 & Siswa 10 & 95 & Tuntas \\
11 & Siswa 11 & 90 & Tuntas \\
12 & Siswa 12 & 90 & Tuntas \\
13 & Siswa 13 & 95 & Tuntas \\
14 & Siswa 14 & 95 & Tuntas \\
15 & Siswa 15 & 95 & Tuntas \\
& Rata-rata & $\mathbf{8 9 , 3 3}$ & \\
\hline
\end{tabular}


Penelitian tindakan kelas ini dilakukan dalam 2 siklus. Dari data yang telah diperoleh menunjukkan terjadinya peningkatan nilai yang cukup baik. Selain itu antusias siswa dalam mengikuti proses pembelajaran ikut meningkat. Sehingga jika dipadukan dengan model pembelajaran Cooperative Integreted Reading and Composition (CIRC) dalam pembelajaran Bahasa Indonesia dapat meningkatkan hasil belajar siswa. Hal ini dapat dilihat dari hasil rekapitulasi hasil belajar siswa seperti pada tabel 3 berikut ini.

Tabel 3. Rekapitulasi Hasil Tes Evaluasi

\begin{tabular}{ccccc}
\hline No & Nama & \multicolumn{3}{c}{ Nilai } \\
\cline { 2 - 5 } & & Pra Siklus & Siklus I & Siklus II \\
\hline 1 & Siswa 1 & 60 & 60 & 95 \\
2 & Siswa 2 & 40 & 80 & 90 \\
3 & Siswa 3 & 70 & 70 & 95 \\
4 & Siswa 4 & 70 & 70 & 90 \\
5 & Siswa 5 & 60 & 60 & 90 \\
6 & Siswa 6 & 80 & 80 & 90 \\
7 & Siswa 7 & 60 & 60 & 70 \\
8 & Siswa 8 & 75 & 75 & 90 \\
9 & Siswa 9 & 65 & 65 & 70 \\
10 & Siswa 10 & 65 & 70 & 95 \\
11 & Siswa 11 & 70 & 75 & 90 \\
12 & Siswa 12 & 65 & 65 & 90 \\
13 & Siswa 13 & 75 & 75 & 95 \\
14 & Siswa 14 & 45 & 75 & 95 \\
15 & Siswa 15 & $\mathbf{6 5 , 0 0}$ & 70 & 95 \\
& Rata-rata & $\mathbf{7 0 , 0 0}$ & $\mathbf{8 9 , 3 3}$ \\
& Ketuntasan & & $\mathbf{6 0 \%}$ & $\mathbf{8 7 \%}$ \\
\hline
\end{tabular}

Perolehan rata-rata nilai pada siklus I meningkat menjadi 70,00 jika dibandingkan dengan nilai pra siklus yang hanya 65,00. Pada siklus II, rata-rata meningkat menjadi 89,33. Pembelajaran dengan menggunakan model pembelajaran Cooperative Integreted Reading and Composition (CIRC) berhasil meningkatkan hasil belajar siswa.

Proses pembelajaran pada siklus I, peneliti menggunakan model pembelajaran Cooperative Integreted Reading and Composition (CIRC). Adapun pada penelitian ini mencakup 4 tahap yaitu tahap perencanaan, pelaksanaan, pengamatan atau observasi dan refleksi. Sebelum dilakukan penelitian, peneliti melakukan observasi di kelas V SDN 4 Bebetin Kabupaten Buleleng. Pada tahap ini hasil tes evaluasi adalah 9 siswa $(60 \%)$ yang tuntas dan yang tidak tuntas 6 siswa (40\%). Dengan demikian hasil belajar siswa pada siklus I mengalami peningkatan sebesar 33\% jika dibandingkan dengan pra siklus. Karena belum memenuhi indikator keberhasil penelitian yang telah ditetapkan sebesar $\geq 75 \%$, maka penelitian dilanjutkan ke siklus II.

Pada siklus II tindakan penelitian mempertimbangkan kekurangan dan kendala yang muncul pada siklus I. Untuk proses pembelajaran masih sama dengan dengan siklus I, yaitu dengan menggunakan model pembelajaran Cooperative Integreted Reading and Composition (CIRC). Pada siklus II telah terjadi peningkatan hasil belajar siswa kelas V SDN 4 Bebetin Kabupaten Buleleng yang signifikasi. Hasil tes evaluasi yang diperoleh pada siklus II, yaitu 13 siswa $(87 \%)$ yang tuntas, sedangkan 2 siswa $(13 \%)$ belum tuntas. Karena sudah memenuhi indikator keberhasilan penelitian sebesar $\geq 75 \%$, maka penelitian dihentikan sampai siklus II. Berdasarkan hasil yang diperoleh pada siklus II, persentase nilai yang diperoleh pada siklus II telah memenuhi indikator keberhasilan penelitian yang telah ditetapkan sebesar $\geq 75 \%$, dengan 
demikian dapat dinyatakan bahwa model pembelajaran Cooperative Integreted Reading and Composition dapat meningkatkan hasil belajar siswa kelas V SDN 4 Bebetin Kabupaten Buleleng.

Model pembelajaran Cooperative Integreted Reading and Composition merupakan salah satu tipe dari model pembelajaran kooperatif dengan menggunakan kelompok-kelompok kecil dengan jumlah anggota tiap anggota 4 sampai 5 orang siswa secara heterogen Model pembelajaran Cooperative Integreted Reading and Composition merupakan suatu cara yang efektif untuk mengganti suasana pola diskusi kelas, dengan diskusi membutuhkan pengaturan untuk mengendalikan kelas secara keseluruhan dan prosedur yang digunakan dalam model pembelajaran Cooperative Integreted Reading and Composition dapat memberi siswa lebih banyak waktu untuk berpikir, merespons dan saling membantu.

Kelebihan dari model pembelajaran Cooperative Integreted Reading and Composition berupa pembelajaran lebih bermakna, siswa dituntut untuk dapat menangkap hubungan antara pengalaman belajar di sekolah dengan kehidupan nyata. Siswa dituntun untuk menemukan pengetahuannya sendiri. Melatih siswa untuk menerima penjelasan dari teman, saling menghargai dan bekerja sama menuntaskan materi yang dipelajari.

Di samping itu, untuk keberhasilan penelitian dengan penerapan model pembelajaran Cooperative Integreted Reading and Composition ini tidak terlepas dari kegiatan-kegiatan tiap siklusnya. Dalam melakukan penelitian penulis merasa perlu melakukan semacam perbaikan pada siklus I atau kegiatan mengulang pada siklus II, di mana masih terdapat beberapa kekurangan baik itu dari kemampuan siswa menguasai materi ataupun cara guru dalam mengelola pembelajaran. Sehingga pembelajaran dengan penerapan model pembelajaran Cooperative Integreted Reading and Composition telah berjalan dengan baik dan adanya peningkatan dari setiap aspek pembelajaran.

\section{PENUTUP}

\section{KESIMPULAN}

Penerapan model pembelajaran Cooperative Integreted Reading and Composition dapat meningkatkan hasil belajar siswa kelas V SDN 4 Bebetin Kabupaten Buleleng. Hal ini dibuktikan dengan adanya peningkatan hasil belajar siswa. Pada pra siklus terdapat 4 siswa (27\%) yang mencapai ketuntasan, sedangkan yang belum tuntas 11 siswa (73\%) dengan nilai rata- rata 65,00. Pada siklus I terjadi peningkatan ketuntasan belajar siswa menjadi 6 siswa (40\%) yang tuntas dan 9 siswa (60\%) belum tuntas dengan nilai rata- rata 70,00. Ketuntasan belajar pada siklus II meningkat lagi menjadi 13 siswa (87\%) yang tuntas dan yang belum tuntas 2 siswa (13\%) dengan perolehan nilai rata-rata 89,33. Pencapaian hasil belajar pada siklus II menyatakan bahwa target pencapaian indikator keberasilan sudah memenuhi, yaitu $87 \%$ dari keseluruhan siswa yang tuntas belajar dari indikator keberhasilan yang ditetapkan, yaitu $\geq 75 \%$ dari total keseluruhan siswa. Berdasarkan hasil yang diperoleh pada siklus II, dengan demikian dapat disimpulkan bahwa model pembelajaran Cooperative Integreted Reading and Composition dapat meningkatkan hasil belajar siswa kelas V SDN 4 Bebetin Kabupaten Buleleng.

\section{SARAN}

Berdasarkan hasil penelitian yang telah dilaksanakan dan telah mencapai keberhasilan maka peneliti memberikan saran. Kepada guru, dengan menggunakan model pembelajaran 
Cooperative Integreted Reading and Composition hendaknya diterapkan kembali dalam proses pembelajaran Bahasa Indonesia karena terbukti dapat meningkatkan hasil belajar siswa pada pelajaran Bahasa Indonesia.

Sebelum melaksanakan kegiatan pembelajaran hendaknya guru melakukan persiapan yang matang telebih dahulu, dengan memahami langkah-langkah yang akan diterapkan dalam proses pembelajaran yang berpedoman pada RPP yang telah disusun sebelumnya. Guru hendaknya memberikan penjelasan mengenai langkah-langkah model pembelajaran Cooperative Integreted Reading and Composition agar siswa tidak merasa bingung dan tidak menyamakan dengan model diskusi lain.

Guru sebaiknya lebih kreatif dan variatif dalam menggunakan model pembelajaran sehingga dapat meningkatkan minat siswa untuk mengikuti proses pembelajaran dengan baik, sehingga tujuan pembelajaran dapat tercapai, serta melibatkan siswa secara aktif dalam proses pembelajaran yang dapat menghilangkan kejenuhan, sehingga hasil belajar siswa dapat meningkat.

Bagi siswa hendaknya lebih aktif dalam bertanya saat tidak mengerti apa yang diajarkan guru, agar tidak mengalami kebingungan saat melakukan kegiatan maupun mengerjakan tugas yang diberikan.

Bagi peneliti lain yang akan mengadakan penelitian lebih lanjut tentang model pembelajaran Cooperative Integreted Reading and Composition, semoga ini bisa dijadikan sebagai acuan ataupun sumber refrensi demi ketuntasan penelitian selanjutnya.

\section{DAFTAR RUJUKAN}

Agung, A. A. Gede. 2005. Metodelogi Penelitian Pendidikan. Singaraja: undiksha Singaraja.

Arikunto, Suhardjono dan Supardi. 2014. Penelitian Tindakan Kelas. Jakarta: PT Bumi Aksara. Ghalia Indonesia.

Darsana, I Made. 2019. Penerapan Model Pembelajaran Blended Learning berbasis WhatsApp untuk Meningkatkan Keaktifan Belajar Siswa Kelas 6 SD Negeri 2 Sawan Semester I Tahun Pelajaran 2019/2020. Skripsi (tidak diterbitkan). Singaraja.

Daryanto. 2011. Penelitian Tindakan Kelas. Yogyakarta: Gava Media.

Depdiknas. 2011. Kurikulum 2006. Jakarta: Depdiknas.

Dimyati dan Mujiono. 2006. Belajar dan Pembelajaran. Jakarta: Rienika Cipta.

Fathurrohman, Muhammad. 2015. Model- Model Pembelajaran Inovatif Alternatif Desain Pembelajaran yang Menyenangkan. Jogjakarta:Ar-Ruzz Media.

Huda, Miftahul. 2013. Model- Model Pengajaran dan Pembelajaran Isu-Isu-Metodis dan Paradigmatis. Yogyakarta:Pustaka Pelajar.

Iskandar Wasid dan Dadang Sunendar. 2008. Strategi Pembelajaran Bahasa. Bandung: PT Remaja Rosdakarya. 
Islami, Zahratul. 2017. Penerapan Model Pembelajaran Kooperatif Circ (Cooperative Integrated Reading And Composition) Untuk Meningkatkan Hasil Belajar Siswa Pada Mata Pelajaran Bahasa Indonesia Di Kelas Iii Min 1 Banda Aceh. Skripsi (tidak diterbitkan). Banda Aceh: Universitas Islam Negeri Ar-Raniry Darussalam.

Mulyasa. 2011. Praktik Penelitian Tindakan Kelas. Bandung: PT Remaja Rosdakarya.

Rahyubi, Heri. 2014. Teori-Teori Belajar dan Aplikasi Pembelajaran Motorik Deskripsi dan Tinjauan Kritis. Bandung: Nusa Media.

Ramlan, dkk. 1994. Bahasa Indonesia Yang Salah dan Benar. Yogyakarta: Andi Offset.

Salam, B. 2002. Pengantar pedagogik (dasar-dasar ilmu mendidik). Jakarta: PT Rineka Cipta.

Sardiman. 1994. Interaksi dan Motivasi Belajar Mengajar. Jakarta: PT. Raja Grafindo Persada.

Slameto. 1991. Belajar dan Faktor- Faktor Yang Mempengaruhinya. Jakarta: Rineka Cipta.

Sudjana, Nana. 2005. Dasar-dasar Proses Belajar Mengajar. Bandung: Sinar Baru Algensindo.

Susanto, Ahmad. 2013. Teori Belajar dan Pembelajaran di Sekolah Dasar. Jakarta: PT Kharisma Putra Utama.

Tarigan, Guntur. 2008. Membaca Sebagai Suatu Ketrampilan Berbahasa. Bandung

Tambubolon, DP.TT. Kemampuan Membaca Teknik Membaca Efektif dan Efisien. Bandung: Offset Angkasa.

Yamin, Martinis. 2012. Desain Baru Pembelajaran Konstruktivistik. Ciputat: Referensi.

Zulela. 2012. Pembelajaran Bahasa Indonesia. Bandung: PT. Remaja. 